\title{
A magyar kultúraszemélyiség észlelésének különbségei a magyarok és a külföldiek között
}

\author{
Szerzők: Malota Erzsébet ${ }^{1}$ - Gyulavári Tamás²
}

Kutatásunk célja a magyar kultúráról, a magyarokról alkotott percepciók feltérképezése. Azt tanulmányoztuk egy 1566 fös online minta felmérése során, hogy a nálunk tanuló külföldi hallgatók hogyan látják a magyarokat és Magyarországot, milyen spontán negatív és pozitív szavakat társítanak hozzánk. Emellett szemantikus differenciálskála használatával vizsgáltuk az észlelt magyar kultúraszemélyiséget, mely során 11 különbözô országból származó hallgatók percepcióit vetettük össze arra fókuszálva, hogy milyen eltérések mutathatók ki a hallgatók származási országát figyelembe véve. A külföldiek észlelésérôl kapott eredményeket összevetettük a magyarokban önmagukról élő képpel.

A leggyakrabban elhangzó pozitív kifejezések rólunk a "szépség”, "kedvesség” és a "barátságosság”, a negatív szavakra rákérdezve pedig legtöbbször azt a választ kaptuk, hogy "nincs negatívum".

Eredményeink azt mutatják, hogy a kultúra személyiségére vonatkozóan minden jellemzôt illetően a külföldiek által adott átlagok a magasabbak, csak két személyiségjegyben értékeljük önmagunkat kedvezóbben: humorosabbnak és különlegesebbnek itéljük meg magunkat, mint a külföldiek. A válaszok alapján eltérések mutathatók ki a külföldiek származási országát tekintve: a fejlettebb országok válaszadói (például a németek és a japánok) kedvezôtlenebb, a kevésbé fejlett országokból származók (például az indiaiak, algériaiak és a nigériaiak) pedig jóval pozitívabb színben látnak bennünket.

Kulcsszavak: kultúraszemélyiség, származási ország, személyiségskála, külföldi hallgatók.

\section{Bevezetés}

Tanmese: Mindenki, aki Bongobongóban él, sárga napszemüveget visel. Számukra természetes, hogy mindennek, amit látnak - az égnek, a fáknak, az ételeknek - sárga árnyalata van. Mindig is így volt, és Bongobongo lakosai nagy megelégedéssel éldegélnek sárga kis világukban. Ebbe a világba érkezik egy vendég a szomszédos Adanac városából. Talán már hallottak róla, minden adanaci kék napszemüveget hord. Amikor reggelente felébrednek, megcsókolják gyönyörü kék gyermekeiket, és az ablakukon kinézve szép kék mezôket, erdőket és farmokat látnak a természetesen tökéletesen kék szinü ég alatt. Mint kulturálisan érzékeny látogató, az adanaci vendég úgy érzi, hogy az egyetlen dolog, amit tehet, hogy megpróbálja megérteni a világot a bongobongói perspektívából. Szerez tehát egy sárga napszemüveget, és felveszi a saját kék napszemüvege fölé. Büszkén és megelégedéssel szögezi le: 'Aha! Most már értem. Itt Bongobongóban minden zöld!'

\footnotetext{
1 egyetemi docens, Budapesti Corvinus Egyetem, erzsebet.malota@uni-corvinus.hu

2 egyetemi docens, Budapesti Corvinus Egyetem,

tamas.gyulavari@uni-corvinus.hu
}

Ez a tanmese elsôsorban azzal a tanulsággal szolgál, hogy a kultúrák „egymáshoz képest ébrednek magukra”: a kulturális különbségek a találkozáskor felszínre kerülnek, a saját kultúránk által berögzült napszemüveget, kulturális referencia keretünket, nézőpontunkat nem tudjuk levenni.

Vajon hogyan látnak minket, magyarokat, a magyar kultúrát a japán, a német, a kínai, a mongol vagy a vietnámi kultúra napszemüvegén keresztül? Ôszintébbnek tart-e bennünket egy indiai, mint egy német (igen), udvariasabbnak érzékel-e egy japán, mint egy vietnámi (nem)?

Megítélésünk természetesen nézőpont függvénye is, a kérdés igen összetett. A válaszok egyrészt függnek az adott személyiségjegytől, és attól, hogy a két kultúra adott személyiségjegy mentén milyen hasonlóságokat vagy különbségeket mutat, másrészt az is befolyásolja, hogy a válaszadó egyént mennyire „zavarja meg" a saját kulturális szemüvege.

A kultúraszemélyiség egy adott kultúrához kapcsolódó személyiségjellemzók összessége (MALOTA - GYULAVÁRI 2016). Kutatásunk fókuszában a magyar kultúraszemélyiség vizsgálata áll, azt tanulmányoztuk, hogy a nálunk tanuló, 11 különbözô országból származó külföldi hallgatók hogyan látják a magyar kultúra személyiségét, és ez mi- 
lyen eltéréseket mutat a hallgató származási országát figyelembe véve.

\section{Szakirodalmi áttekintés}

A kultúra és a személyiség témaköre külön-külön is régóta kutatott terület. A személyiséggel kapcsolatos kutatások hazánkban is számos területen megjelennek, például a marketingkutatók körében a márkaszemélyiség kapcsán (KUNSÁGI 1999, HOFMEISTER et al. 2002, TÖRŐCSIK 2007, PRÓNAY 2011, KÁZÁR 2014, PISKÓTI 2015, NÉMETH 2017). Témánk, a kultúraszemélyiség koncepciója viszont meglehetősen új a szakirodalomban.

Mint sok pszichológiai fogalom, a személyiség is olyan elvont konstrukció, melynek meghatározása sok disputa forrása a szakirodalomban, és amelyre vonatkozóan teljes egyetértés nem alakult ki. Olyan meghatározások jelentek meg, amelyek vagy nagyon specifikusak, és egy-egy külön elméleti irányzatot képviselnek, vagy nagyon általánosak. Utóbbira példa ALLPORT (1937:48) meghatározása, aki korának 49 definícióját gyújtötte össze, és szintetizálta: „,a személyiség azon pszichofizikai rendszereknek a dinamikus szerveződése az egyénen belül, amelyek meghatározzák a környezethez való egyedi alkalmazkodást". Vagyis Allport az egyén környezetre adott reakcióit az egyénre jellemző pszichológiai és fizikai folyamatok összességére vezeti vissza, amelyek még napjainkban is feltáratlanok. A fogalom definíciója meglehetősen általános, amely a személyiség valamilyen szintú megfoghatatlanságára, a közvetlen mérés nehézségeire utal. Az értelmezés Allport óta sem nagyon változott. CARVER és SCHEIER (2006:30-31, idézi PISKÓTI 2015) szerint például „a személyiség a személyen belüli pszichofizikai rendszerek olyan dinamikus szerveződése, amely a személyre jellegzetes viselkedés-, gondolat- és érzésmintázatokat létrehozza".

A kultúrára vonatkozóan szintén rengeteg eltérố definíciót találunk a szakirodalomban, annak eltérő aspektusaira koncentrálva. MALOTA (2013) négy csoportba sorolta a kultúrafogalmakat. Az elsố csoport a kultúra általános, rendszerszemléletú definíciói, melyek közül az egyik legátfogóbb kultúrafogalom a következő: „A kultúra egy adott szimbólumkészlet - történelem folyamán - közösen kialakított rendszere, mely a világunkat érthetóvé teszi" (HALL 2005:4).

A második nagy csoport az értékek, hitek, magatartási szabályok összességére épító definíciók. A legtöbb kultúrafogalom ebbe a kategóriába sorolható, a kulturális különbségek „mérése” is leginkább a kulturális értékek vizsgálatán alapszik
(HOFMEISTER - NEULINGER 2013). A definíciók az értékek mellett sokszor magukba foglalják a kultúra további elemeit, mint például hitvilág, babonák, rítusok, nyelv, normák. Az egyik legkorábbi definíció - mely az e csoportba tartozó késóbbi definíciókat is megalapozta - TYLORTÓL (1958:1) származik. Szerinte "a kultúra komplex egész, mely tudást, hiteket, erkölcsöt, szokásokat, viselkedésformákat és képességeket tartalmaz egy adott társadalom tagjaira nézve".

A harmadik az orientációközpontú definíciók csoportja, mely definíciók lényege, hogy a kultúrát úgy értelmezik, hogy az elósegíti a világban való orientációt, megfeleló keretet és segítséget nyújtva a mindennapi élet problémamegoldásaihoz.

A kultúra rétegeire épító definíciók, modellek képezik a negyedik csoportot, ezek a definíciók a kultúra elemeit és rétegeit hangsúlyozzák. Egy nagyon lényeges szempontra világítanak rá, mégpedig arra, hogy a kultúra sokszor automatikus, hiszen tudatalatti, láthatatlan rétegeket is magában foglal.

Egy átfogó definíció szerint „a kultúra egy adott társadalmi csoport által közösen kialakított látható és láthatatlan rendszer, mely - hiedelmeken, normákon, értékeken, szimbólumokon, szabályokon, viselkedésformákon, standardokon, szokásokon keresztül - útmutatást, orientációt, életmódot és probléma-megoldási sémákat nyújt tagjai számára" (MALOTA 2013:25). A téma egyik legismertebb kutatója, HOFSTEDE (2001:9) szerint a kultúra a "gondolkodás kollektív programozása, amely megkülönbözteti egy csoport vagy egy kategória tagjait másoktól".

A kultúra és a személyiség kapcsolódását a nemzeti karakter fogalmához köthetjük, mely INKELES és LEVINSON (1969:435) azóta is gyakran hivatkozott meghatározása szerint "azon relatíve tartós személyiségi jellemzók és minták összessége, amelyek leginkább előfordulnak az adott társadalom tagjai között". LEE és szerzôtársai (1999) könyvükben körbejárják azt a témát, hogy miben hasonlít, és miben különbözik az emberek személyisége adott kultúrán belül és a különböző kultúrák között.

A téma bizonyos aspektusait országimázs $k u-$ tatásokban is megtalálhatjuk, például HESLOP és szerzőtársai (1993) országimázs-modelljükben az amúgy erôsen korreláló két fogalmat, az emberek és az ország imázsát, külön fogalmakként kezelik, tehát az emberekról alkotott képet nem az országimázs részeként értelmezik, és külön skálával mérik. D'ASTOUS és BOUJBEL (2007) olyan ország-személyiség skála kifejlesztésére törekedtek, amely a vizsgált terület esetében relevánsabb, mint a szakirodalomban elérhetô általános személyiségskálák, így szorosabban függnek össze 
Lektorált tanulmányok

az országok megítélésével. Az általuk kifejlesztett skála hat dimenziót tartalmaz, melynek fogalmi érvényességét a kongruitás-elmélet alapján ellenőrizték, azaz, megvizsgálták, hogy valóban előrejelzi-e az országok közti preferenciát, ahogy azt a korábbi modellek kimutatták.

Kutatásunk szempontjából lényeges, hogy a különbözó pszichológiában és marketingben használatos személyiségskálák (például Big Five, Aaker féle márkaszemélyiség skála) alkalmazhatósága kultúrafüggó. Több kutatás számol be arról, hogy adott skálákat más kulturális háttér kontextusban nem sikerült maradéktalanul adaptálni (például HOFMEISTER et al. 2002, ALLIK 2005, AHMAD - THYAGARAJ 2014, PÉTER et al. 2013, PÉTER NÉMETH 2016).

\section{A kutatás módszertana, a minta jellemzói}

A saját kultúraszemélyiség-skála fejlesztését a szakirodalom által javasolt eljárás szerint indítottuk el, és a fogalom értelmezése után (CHURCHILL 1979, ROSSITER 2002), feltáró kutatással (lásd GYULAVÁRI et al. 2014) kerestük a releváns skálatételeket. Kiindulási alapként a 2004 és 2012 között (7-7 ôszi, illetve tavaszi szemeszterben) oktatott külföldi cserediákok következó kérdésre adott válaszai szolgáltak: „A kultúrát sokszor értelmezik úgy, mint egy adott társadalom személyiségét. Ha országod egy személy lenne, milyen személyiségjellemzőkkel írnád le?" Az így nyert, összesen 520 (42 kultúráról szóló) kultúraszemélyiség-leírás alapján a leggyakrabban használt személyiségjelzőkből listát készítettünk. 2012-ben az így kapott skálatételeket kettós vizsgálatnak, ellenőrzésnek vetettük alá. Egyrészt 48 MBA hallgatóval történt e témában személyes interjú az egyes tételek megfelelőségéról. Másrészt 70 nemzetközi gazdálkodás szakos, végzős hallgatót az interkulturális kommunikáció tantárgy elméleti modellekról szóló előadásai után felkértünk, hogy 4-5 fős csoportokban válaszoljanak arra a kérdésre, hogy „Milyen kultúrajellemzőket lehet még alkalmazni a kultúrák közötti különbségek mérésére a modellekben szereplókön kívül?".

A fenti három módszerrel kapott eredmények alapján 51 skálatételt alakítottunk ki, amelyet angol és francia nyelvre fordítottunk le, és ezzel párhuzamosan ellenóriztük és finomítottuk a skála tételeinek megfogalmazását és bipolaritását. A skálatételek kialakításához pszichológust, közgazdászt, anyanyelvi és kettős anyanyelvú fordító-lektort alkalmaztunk.

A skálatételek kialakítása többszöri, eltérő mintán történt ellenőrzéssel és validálással zajlott, me- lyet követően 20 tételes skálát véglegesítettünk.

A kvantitatív kutatás során online kérdőívet használtunk, melyet a hazánkban tanuló külföldi hallgatók töltöttek ki. A felmérés 2016 júniusában zajlott, a minta végleges elemszáma 1566 fó̉. A válaszadók 72 különböző országból érkeztek hazánkba tanulni, adatbázisunk 27 hazai felsôoktatási intézmény hallgatóinak válaszait tartalmazza. A kutatás mintavétel helyett a teljes körú megkérdezésre törekedett, ahol a mintavételi keretet a kutatás ideje alatt hazánkban tartózkodó külföldi felsőoktatási hallgatók tették ki (GYULAVÁRI et al. 2014).

A válaszadók közül a legtöbb külföldi hallgató Kínából (11\%), Jordániából (9\%), Vietnámból (6\%), valamint Tunéziából, Japánból, Nigériából, Algériából, Törökországból (5-5\%), Mongóliából és Indiából (4-4\%), valamint Németországból (3\%) származik. Ebból a 11 országból érkezó hallgatók teszik ki a minta közel 65 százalékát, és mivel az elemszámok ezen országokból megfelelő mennyiségúek az elemzéshez, a különbségek vizsgálatakor az ő véleményüket hasonlítjuk össze a magyarok saját magukról alkotott képével.

A külföldi hallgatók jórészt Erasmus és Stipendium Hungaricum ösztöndíjjal érkeztek hazánkba; túlnyomó többségük (92\%) egy vagy két évet tanult eddig Magyarországon.

A magyar hallgatók mintája 216 fóből áll, és szintén egyetemi hallgatók véleményét tükrözi, az adatfelvétel 2012-ben készült.

A kultúraszemélyiséget a MALOTA és GYULAVÁRI (2014) által kifejlesztett skála rövidített, 20 tételes változatával mértük. Az adatokat az SPSS.22 statisztikai programcsomag segítségével elemeztük.

\section{Eredmények}

\subsection{MAGYARORSZÁG IMÁZSA SPONTÁN POZITÍV ÉS NEGATÍV ASSZOCIÁCIÓK ALAPJÁN}

Magyarország általános imázsát nyílt kérdések keretében mértük, hasonlóan ahhoz, ahogy ezt Péter tette 2015-ben megjelent könyvében (PETTER 2015). A megkérdezetteknek arra a kérdésre kellett válaszolniuk, hogy mi az első három pozitív és az első három negatív szó, ami eszükbe jut, ha Magyarországra, a magyarokra gondolnak (ezen eredményeknél a teljes sokaság véleményét ismertetjük, a válaszok nincsenek leszúrve a későbbiekben kiemelt 11 ország válaszadóira).

Pozitívumként legtöbben a szépségre (említések

3 A kutatás nem reprezentatív, mivel a külföldi hallgatók populációja nem határozható meg pontosan, azonban a Stipendium Hungaricum hallgatók nagy százaléka válaszolt, így rájuk vonatkozóan érvényes megállapításokat fogalmazhatunk meg. 
Spontán említések Magyarországról és a magyarokról

1. ábra (első három pozitív, elsố három negatív szó)

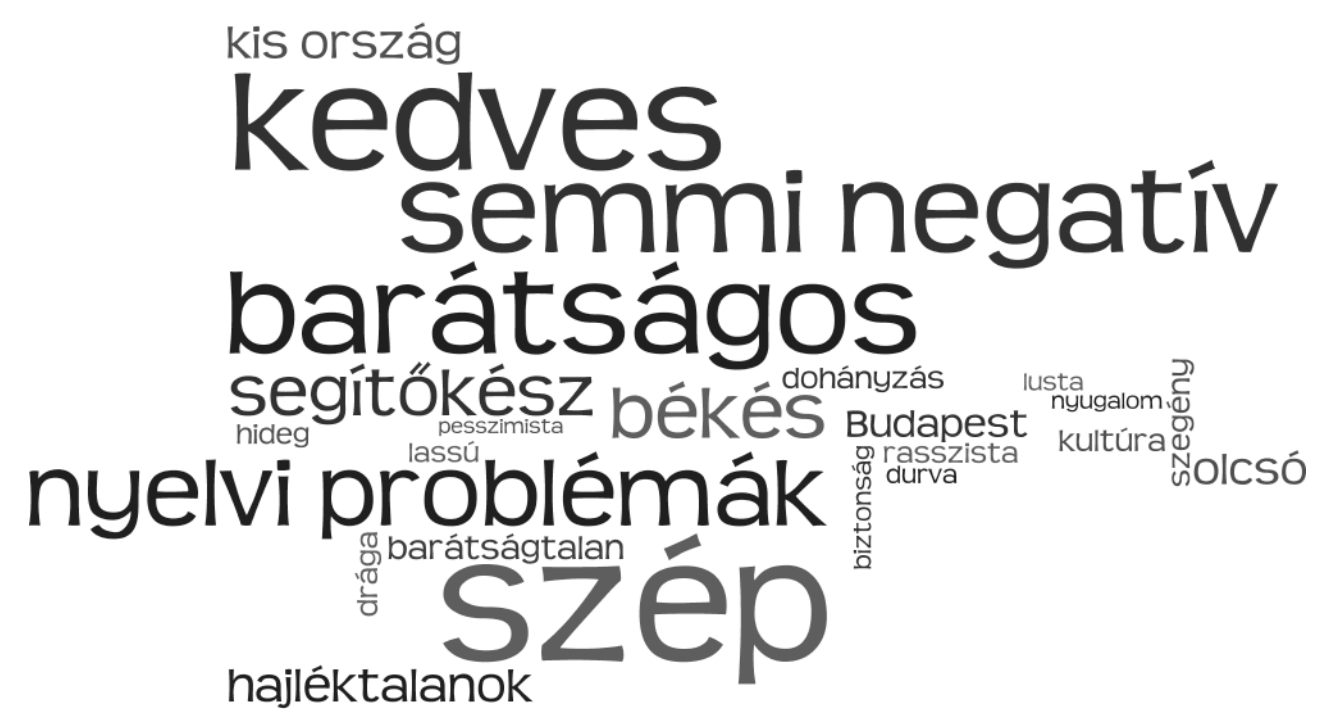

Említések száma $=4698$ (1566 X 3)

Forrás: saját szerkesztés

9\%-a), kedvességre (8\%), barátságosságra (7\%) aszszociáltak. A pozitív kifejezések közül a fentieken kívül a leggyakrabban kerültek említésre még a következők: békés, segítőkész, olcsó/megfizethető, Budapest, kultúra, biztonságos, nyugodt. Előfordultak vicces szavak is, 1-2 említéssel magyarul az angol kérdőívben: palacsinta, Laci bácsi, erős tanulás, köszönöm, mangalica, valamint például a „Cubik-Rubik”.
A leggyakoribb válasz arra a kérdésre, hogy mi az első három negatív szó, ami a megkérdezettnek országunkról és a magyarokról eszébe jut, az volt, hogy "nincs negatívum”, többször elófordult az is, hogy az első két szó után a harmadik már a „nincs több” volt (összesen 7\%). (A pozitív jelzóknél mindössze 9 válaszadó volt, aki kihúzta, vagy nem tudott 3 választ adni e kérdésre, tehát a hallgatók nem lustaságból hagyták ki a választ, valóban

Magyarország kultúraszemélyiség-jellemzơii a külföldi hallgatók szerint (2016-os teljes minta átlag)

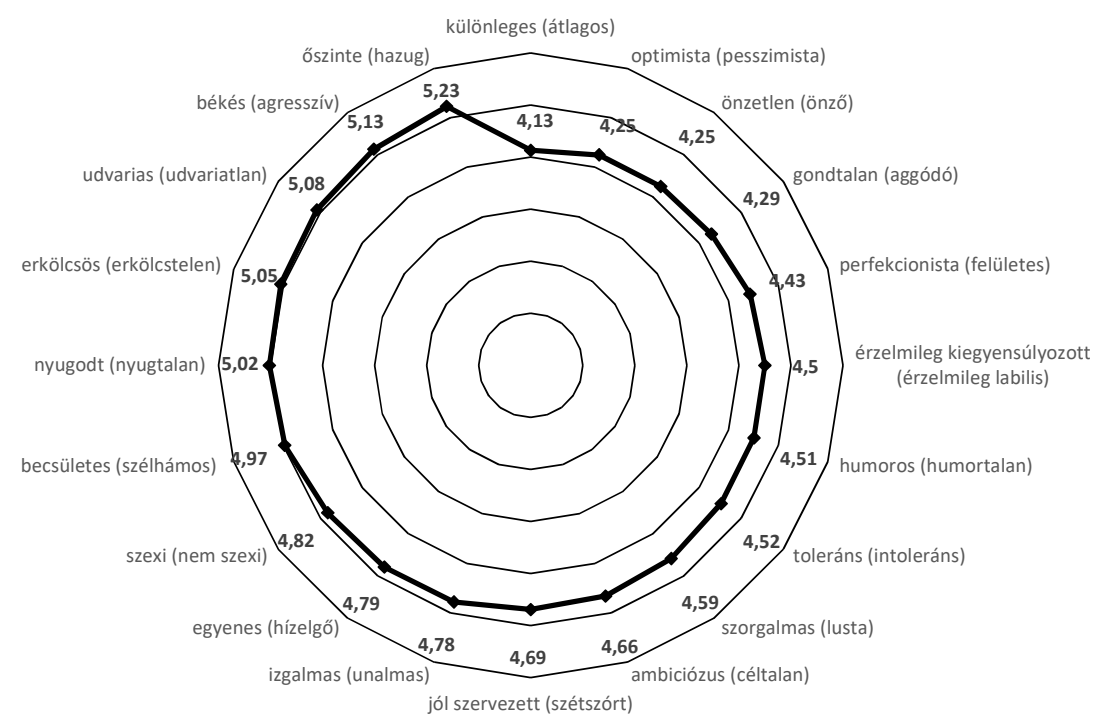


Lektorált tanulmányok

nem tudtak, vagy nem akartak negatív szavakat felsorolni.) Ezután sorrendben a következó negatív szavak következtek: nyelv/nyelvi nehézségek (5\%), hajléktalanok $(3 \%)$, kis ország $(3 \%)$, barátságtalan $(2 \%)$, szegény, szegénység, dohányzás, drága, raszszista $(2-2 \%)$.

Feltúnó, hogy a pozitív szavakban nagyobb az egyetértés, magasabbak az említési százalékok (sorrendben az első három esetében 7-9\%), míg a negatív kifejezéseknél alacsonyabbak az arányok (az első három esetében 3-7\%), viszont többféle szó jelenik meg. A fentieket az 1. ábrán látható szófelhőben jelenítjük meg, csoportosítva a válaszokat.

\subsection{A MAGYAR KULTÚRA SZEMÉLYISÉGJELLEMZÖINEK MEGÍTÉLÉSE}

A felmérés során a megkérdezetteknek értékelniük kellett a magyar kultúrát, mint személyiséget. Ehhez az általunk kifejlesztett és validált 7 fokozatú szemantikus differenciál kultúraszemélyiség skálát használtuk.

A külföldi hallgatók a magyarokat leginkább őszintének tartják (5,23-as átlag a hetes skálán). Szintén viszonylag magas (valamivel 5 feletti) átlagot kaptunk a békés, udvarias, erkölcsös, nyugodt jellemzókre. Legkevésbé optimistának, önzetlennek és különlegesnek észlelnek bennünket. (A szórás értékei 1,31-1,69 között vannak). A 2. ábrán a 2016-os teljes minta polaritás profilját mutatjuk be.

A nők agresszívebbnek, intoleránsabbnak, lustábbnak és hanyagabbnak vélik a magyar kultúra személyiségét, mint a férfiak; egyéb jellemzőket illetően nem volt különbség a két nem átlagai között.

Több tulajdonság értékelése is egyenes arányban van a származási ország gazdasági fejlettségével (az egy fóre eső GDP figyelembevételével), minél kevésbé fejlett országból származik a válaszadó, annál ambiciózusabbnak, humorosabbnak, toleránsabbnak, ôszintébbnek, nyugodtabbnak és becsületesebbnek észlel bennünket.

A „toleráns" személyiségjegy esetében igen élesek a különbségek az átlagokban: az elmaradott országokból származók által adott átlagérték 4,81, a fejletlen országok esetében 4,65, a közepesen fejlett országoknál 3,86, a fejlett országok válaszadóinál pedig 2,85 .

Az erkölcsösség és az ôszinteség megitélése befolyásolja azt, hogy újra visszajönne-e hozzánk a hallgató tanulni, minél erkölcsösebbnek és őszintébbnek lát bennünket, annál inkább választaná újra hazánkat tanulmányai színhelyéül.

\subsection{A MAGYAR KULTÚRA MINT IDEÁLIS TURISZTIKAI, ÜZLETI ÉS OKTATÁSTURISZTIKAI CÉLPONT, ÉS ANNAK ÖSSZEFÜGGÉSEI A KULTÚRASZEMÉLYISÉG-JELLEMZÖKKEL}

Kutatásunkban megjelenik egy olyan kérdéskör, hogy a hallgatók mennyire tartják ideális turisztikai, üzleti, és oktatásturisztikai célpontnak hazánkat. Turisztikai célpont alatt általános turizmust értünk, vagyis mennyire szívesen látogatnának hazánkba, mint turisták. Az üzleti célpontot illetóen azt kérdeztük meg a hallgatóktól, hogy menynyire szívesen választanának üzleti partnert az országból. Az oktatásturizmust illetően pedig az volt a felmerüló kérdés, hogy mennyire tartják ideálisnak hazánkat az oktatás szempontjából (lévén cserediákok és reguláris hallgatók voltak a megkérdezettek).

Arra kértük a kérdőívet kitöltóket, hogy értékeljék 1-7-ig terjedő skálán Magyarországot a tekintetben, hogy mennyire tartják ideális turisztikai, oktatásturisztikai és üzleti/befektetési célpontnak (a három változó közepesen erős korrelációt mutat, a Pearson korrelációs mutatók: 0,43 és 0,52 között vannak, szignifikancia szint: $p<0,00$ ).

Válaszadóink véleménye szerint Magyarország ideális turisztikai célpont a 7-es skálán 5,79-es átlaggal, közel hasonlóan ideális oktatásturisztikai célpont 5,45-ös átlagértékkel, és közepesnél kicsivel jobban ideális üzleti célpont 4,62-es értékkel.

Országunk turisztikai célpontként való megítélése összefüggésben van az észlelt kultúraszemélyiséggel, a regressziós elemzés hét változóval mutat kapcsolatot $\left(R^{2}=0,25\right)$. Minél becsületesebbnek, izgalmasabbnak, erkölcsösebbnek, szexibbnek, különlegesebbnek, ambiciózusabbnak, nyugodtabbnak véli a hallgató a magyar kultúrát, annál inkább látja hazánkat ideális turisztikai célpontnak.

Oktatásturizmus szempontjából valamivel erôsebb a kapcsolat $\left(R^{2}=0,28\right)$. A következó jellemzők pozitívabb értékelése hozza magával azt, hogy a megkérdezett ideálisnak látja országunkat oktatási helyként: becsületes, szorgalmas, izgalmas, ambiciózus, erkölcsös, őszinte, jól szervezett, különleges.

$\mathrm{Az}$ üzleti célpontot illetően hasonló jellemzők kapcsolódnak az ideális megítéléshez $\left(\mathrm{R}^{2}=0,27\right)$. A fentiekhez képest új kapcsolódási pontok a humor és az önzetlenség.

A várakozásoknak megfelelóen természetesen szoros korreláció (Pearson korrelációs mutató: 0,39 $\mathrm{p}<0,00)$ mutatható ki aközött, hogy a hallgató ideális oktatásturisztikai célpontnak érzi-e hazánkat és aközött, hogy újraválasztaná-e Magyarországot tanulmányai színhelyeként. Akik visszajönnének 5,87-es, akik talán visszajönnének 4,70-es, akik 
nem jönnének újra hozzánk 2,89-es átlagot adtak a hetes skálán arra a kérdésre, hogy Magyarország ideális oktatásturisztikai célpontnak tekinthető-e.

4.4. A MAGYAR KULTÚRA SZEMÉLYISÉGJELLEMZŐINEK MEGÍTÉLÉSE 11 KÜLÖNBÖZŐ ORSZÁGBÓL SZÁRMAZÓ VÁLASZADÓKÉS AMAGYAROK SZEMÜVEGÉN KERESZTÜL
A továbbiakban azt vizsgáltuk az ANOVA módszer segítségével, hogy az eltérő származású válaszadók véleményei között milyen különbségeket találunk.

Az 1. táblázatban összefoglaljuk a kapott eredményeket, a teljes átlagnál magasabb értékeket félkövér, a teljes átlagnál alacsonyabb értékeket dőlt betúvel jelezzük.

1. táblázat

Magyarország kultúraszemélyiség jellemzői 11 különbözó országból származó válaszadók és a magyarok szerint (N=963 külföldi, N=216 magyar) (a teljes átlagnál magasabb érték félkövér, a teljes átlagnál alacsonyabb érték dólt betúvel)

\begin{tabular}{|c|c|c|c|c|c|c|c|c|c|c|c|c|c|}
\hline $\begin{array}{c}\text { kultúra-személyiség } \\
\text { jellemzők } \\
1-7 \text { skála }\end{array}$ & 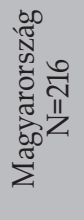 & 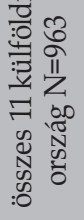 & 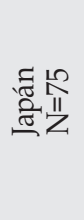 & 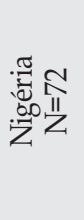 & 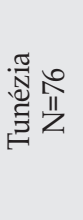 & 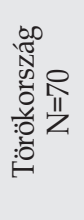 & 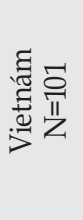 & 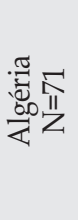 & 湾竞 & 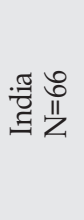 & 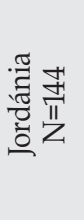 & 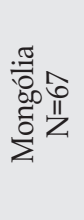 & 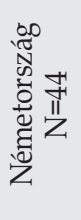 \\
\hline $\begin{array}{c}\text { békés } \\
\text { (agresszív) }\end{array}$ & 3,49 & 5,38 & 4,31 & 5,58 & 5,38 & 5,11 & 5,56 & 5,94 & 5,47 & 6,02 & 5,35 & 4,90 & 4,18 \\
\hline ambiciózus (céltalan) & 3,72 & 4,71 & 4,12 & 5,21 & 4,70 & 4,51 & 4,73 & 4,77 & 4,52 & 5,32 & 4,88 & 4,46 & 3,84 \\
\hline $\begin{array}{l}\text { gondtalan } \\
\text { (aggódó) }\end{array}$ & 2,30 & 4,37 & 3,99 & 4,50 & 4,39 & 3,97 & 4,08 & 4,73 & 4,86 & 3,97 & 4,31 & 4,30 & 3,89 \\
\hline különleges (átlagos) & 4,75 & 4,00 & 4,43 & 4,63 & 4,04 & 4,04 & 3,85 & 3,76 & 3,85 & 4,26 & 3,90 & 3,58 & 4,98 \\
\hline izgalmas (unalmas) & 4,76 & 4,78 & 4,69 & 4,76 & 4,97 & 4,87 & 4,75 & 4,97 & 4,80 & 5,21 & 4,60 & 4,37 & 5,00 \\
\hline $\begin{array}{c}\text { jól szervezett } \\
\text { (szétszórt) }\end{array}$ & 3,29 & 4,87 & 3,36 & 5,43 & 5,01 & 4,24 & 4,74 & 5,54 & 4,81 & 5,58 & 5,18 & 4,73 & 3,11 \\
\hline $\begin{array}{c}\text { érzelmileg } \\
\text { kiegyensúlyozott } \\
\text { (labilis) }\end{array}$ & 3,12 & 4,55 & 3,77 & 4,58 & 4,36 & 4,06 & 4,75 & 4,92 & 4,81 & 5,14 & 4,35 & 4,64 & 4,20 \\
\hline egyenes (hízelgő) & 4,00 & 4,82 & 4,51 & 5,07 & 4,67 & 4,34 & 5,02 & 4,86 & 4,95 & 5,36 & 4,69 & 4,55 & 4,45 \\
\hline $\begin{array}{c}\text { humoros } \\
\text { (humortalan) }\end{array}$ & 5,40 & 4,65 & 4,75 & 4,64 & 4,42 & 4,64 & 4,49 & 4,25 & 4,86 & 5,20 & 4,55 & 4,61 & 4,68 \\
\hline $\begin{array}{c}\text { erkölcsös } \\
\text { (erkölcstelen) }\end{array}$ & 4,28 & 5,16 & 4,56 & 4,68 & 5,08 & 4,74 & 5,56 & 5,28 & 5,60 & 5,70 & 4,85 & 5,10 & 4,20 \\
\hline $\begin{array}{c}\text { udvarias } \\
\text { (udvariatlan) }\end{array}$ & 4,43 & 5,28 & 4,60 & 5,03 & 5,18 & 4,83 & 5,62 & 5,73 & 5,53 & 6,06 & 4,99 & 5,15 & 4,30 \\
\hline toleráns (intoleráns) & 3,48 & 4,69 & 4,27 & 4,96 & 4,67 & 4,34 & 4,81 & 5,01 & 4,81 & 5,24 & 4,43 & 4,45 & 3,25 \\
\hline szorgalmas (lusta) & 3,59 & 4,57 & 3,51 & 4,85 & 4,96 & 4,14 & 4,65 & 5,24 & 4,30 & 5,11 & 4,78 & 4,43 & 4,18 \\
\hline $\begin{array}{l}\text { őszinte } \\
\text { (hazug) }\end{array}$ & 3,87 & 5,33 & 4,69 & 5,68 & 4,92 & 4,91 & 5,50 & 5,41 & 5,72 & 5,97 & 5,13 & 5,03 & 4,57 \\
\hline $\begin{array}{c}\text { perfekcionista } \\
\text { (hanyag/felületes }\end{array}$ & 3,74 & 4,51 & 3,44 & 4,68 & 4,57 & 4,17 & 4,42 & 5,07 & 4,58 & 5,21 & 4,56 & 4,39 & 3,50 \\
\hline $\begin{array}{c}\text { szexi } \\
\text { (nem szexi) }\end{array}$ & 4,63 & 4,97 & 4,51 & 5,46 & 5,45 & 5,06 & 4,41 & 5,07 & 4,71 & 5,38 & 5,24 & 4,84 & 4,00 \\
\hline $\begin{array}{c}\text { optimista } \\
\text { (pesszimista) }\end{array}$ & 1,99 & 4,49 & 3,92 & 4,89 & 4,57 & 3,61 & 4,32 & 5,15 & 4,90 & 5,03 & 4,33 & 3,84 & 3,11 \\
\hline nyugodt (nyugtalan) & 2,97 & 5,16 & 4,59 & 5,26 & 4,97 & 5,31 & 4,97 & 5,63 & 5,14 & 5,77 & 4,99 & 5,39 & 4,43 \\
\hline $\begin{array}{c}\text { önzetlen } \\
\text { (önzô) }\end{array}$ & 3,26 & 4,32 & 3,41 & 4,82 & 3,80 & 4,04 & 4,68 & 4,58 & 4,67 & 5,00 & 4,07 & 3,85 & 3,59 \\
\hline $\begin{array}{l}\text { becsületes } \\
\text { (szélhámos) }\end{array}$ & 4,01 & 5,06 & 4,39 & 5,29 & 4,76 & 4,77 & 4,99 & 5,34 & 5,40 & 5,83 & 4,85 & 4,78 & 4,27 \\
\hline
\end{tabular}

Forrás: saját szerkesztés 
Lektorált tanulmányok

Az eredményekből első látásra kitúnik, hogy a magyar kultúra személyiségét a külföldiek sokkal pozitívabban észlelik, mint a magyar válaszadók. Két tulajdonságot kivéve minden személyiségjellemzôt illetôen magasabbak a külföldiektól kapott átlagok. Két jellemző esetében értékeljük önmagunkat kedvezőbben: humorosabbnak és különlegesebbnek látjuk magunkat, mint a külföldiek. Bizonyos tulajdonságok esetében az eltérések igen nagyok, például 7-es skálán a magyarok 1,99-es, a külföldiek 4,49es átlagot adtak az „optimista” jelzőre. Hasonlóan nagyok a különbségek a "gondtalan" és a "nyugodt" jellemzőre vonatkozóan.

A külföldiek származási országa szignifikáns mértékben befolyásolja, hogyan látják kultúránkat. Általánosságban elmondható, hogy a fejlettebb országok válaszadói (például a németek és a japánok) kedvezőtlenebb, a kevésbé fejlett országokból származók (például az indiaiak, algériaiak és a nigériaiak) jóval előnyösebb színben látnak bennünket. Megjegyzendó azonban, hogy nem egy jellemzó válaszadási tendenciáról van szó, mivel bizonyos személyiségjegyeket illetően előfordulnak ellentétes eredmények. A németek például általában az átlagnál alacsonyabb átlagokat adtak négy változó kivételével mindegyik jellemzőre, de különlegesebbnek és izgalmasabbnak látnak minket, mint az átlag. Az indiaiak szinte mindenben pozitívabban észlelnek bennünket, de például aggódóbbnak érzékelnek, mint a teljes minta.

\section{Következtetések és javaslatok, további kutatási irányok}

A kutatás fó korlátai a két minta és az idóbeliség eltérései: a két megkérdezett csoport - külföldiek és magyarok - közti nagy számbeli különbség torzíthatja a kapott eredményt, ami igaz a két kutatás időbeli eltérésére is. Mindemellett eredményeink alapján több következtetés is levonható, és javaslatok fogalmazhatóak meg.

Előző kutatások kimutatták, hogy az oktatásturisztikai célország megválasztásakor az egyik legfontosabb befolyásoló tényező a korábbi tapasztalatokkal rendelkezó, hazatért hallgatók, barátok véleménye. Emiatt igen fontos, hogy a nálunk tanuló külföldi hallgatók véleményét megismerjük, és az ôket megcélzó kommunikáció kialakításakor hasznosítsuk a kapott eredményeket.

Az eredmények alapján elmondható, hogy az észlelt kultúraszemélyiség az országgal kapcsolatos attitúdök varianciájának meglehetôsen nagy hányadával összefüggésbe hozható (25-28\%). Ennek nyomon követése tehát nagymértékben segíthet megérteni a potenciális turisták, üzleti partnerek jövőbeli magatartását.
Néhány személyiségvonás különösen fontos lehet, hiszen mindhárom - általános turisztikai, oktatásturisztikai és üzleti célpont - kontextusban összefüggenek a válaszadók körében hazánkkal szembeni attitûdök formálódásában. Ha mindhárom területen vonzónak szeretnénk látszani, akkor arra kell törekednünk, hogy egyrészt különlegesnek, izgalmasnak, másrészt becsületesnek és erkölcsösnek kell, hogy észleljenek bennünket. A kommunikációnak ezen a területen erősödnie kell, hiszen például átlagosan a különlegesség tekintetében kaptuk a legalacsonyabb értékelést. Fontos figyelmet fordítani arra, hogy az egyes célcsoportokat megkülönböztetve, a megfeleló személyiségjellemző́k mentén kommunikáljunk a potenciális hallgatók felé a magyar kultúráról, mert a vélemények erôsen szóródnak. A legnagyobb kereskedelmi partnerünktól, Németországból érkezô hallgatók például pont a különlegesség és az izgalmasság mentén láttak minket a legpozitívabbnak.

A belső kommunikáció irányait is ki kell jelölni, hiszen meglepó módon jóval negatívabb az önmagunkról kialakult kép, mint a külföldiek rólunk szóló véleménye.

A kutatás további iránya lehet annak megállapítása, hogy a feltárt összefüggések más országok esetében is ugyanilyen paraméterekkel írhatók-e le, melyre több ország esetében létező nagyobb minta felmérésekor van lehetôség. Fontos vizsgálni a véleményeket annak függvényében is, hogy mennyi időt töltött el a hallgató hazánkban, illetve ugyanannak a hallgatónak a véleményében tapasztalunk-e mérhetó változásokat például 1-2 év múlva.

\section{Köszönetnyilvánítás}

Az adatbázis a Tempus Közalapítvány EFOP-3.4.2VEKOP-15-2015-00001 projekt keretében készült.

\section{Felhasznált irodalom}

AHMAD, A. - THYAGARA, K. S. (2014): Applicability of Brand Personality Dimensions across Cultures and Product Categories: A Review. Global Journal of Finance and Management. 6(1). pp. 9-18.

ALLIK, J. (2005): Personality dimensions across cultures. Journal of Personality Disorders. 19(3). pp. 212-232.

ALLPORT, G. W. (1937): Personality: a psychological interpretation. New York: Holt and Company.

CARVER, C. S. - SCHEIER, M. F. (2006): Személyiségpszichológia. Osiris Kiadó, Budapest.

CHURCHILL, G. A. Jr. (1979): A Paradigm for 
Developing Better Measures of Marketing Constructs. Journal of Marketing Research. 16(1). pp. 64-73.

D'ASTOUS, A. - BOUJBEL, L. (2007): Positioning countries on personality dimensions: Scale development and implications for country marketing. Journal of Business Research. 60(3). pp. 231-239.

GYULAVÁRI T. - MITEV A. - NEULINGER Á. - NEUMANN-BÓDI E. - SIMON J. - SZÜCS K. (2014): A marketingkutatás alapjai. Akadémiai Kiadó, Budapest.

HALL, B. J. (2005): Among Cultures, the Challenge of Communication. Thomson Wadsworth, Belmont, CA.

HESLOP, L. A. - PAPADOPOULOS, N. BAMOSSY, G. J. (1993): Country and product perceptions: measurement scales and image interactions. In: Raaij, F. V. - Bamossy, G. J. (eds): European Advances in Consumer Research. 1. Provo, UT: Association for Consumer Research. pp. 198-205.

HOFMEISTER, Á. - KUNSÁGI, A. - NEULINGER, Á. (2002): Brand Personality Research in a Different Cultural Setting. Annual Conference of the Academy of Marketing. Nottingham. Proceedings CD.

HOFMEISTER, Á. - NEULINGER, Á. (2013): Characteristics of materialism and its measurement: assessing the Belk's materialism scale in Hungary. International Journal of Consumer Studies. 37(3). pp. 320-326.

HOFSTEDE, G. (2001): Culture's Consequences: Comparing Values, Behaviors, Institutions and Organizations Across Nations. London: Sage.

INKELES, A. - LEVINSON, D. J. (1969): National character: The study of modal personality and sociocultural systems. In: Lindzey, G. - Aronson, E. (eds.): The handbook of social psychology IV. pp. 418-506.

KAZÁR K. (2014): Fesztivállátogatást befolyásoló tényezők vizsgálata fókuszálva a márka szerepére. In: Hetesi E. - Révész B. (szerk.): Marketing megújulás. MOK 20. Konferenciája, Szeged. Konferenciakötet. pp. 49-60.

KUNSAGI A. (1999): A márkaválasztás háttere a személyiségelméletek alkalmazási lehetôségei a fogyasztói magatartás kutatásában. Doktori (PhD) értekezés. Budapesti Corvinus Egyetem, Gazdálkodástudományi Doktori Iskola, Budapest.

LEE, Y.-T. - McCAULEY, C. R. - DRAGUNS, J. G. (eds) (1999): Personality and Person Perceptions
Across Cultures. Mahwah, NJ, US: Lawrence Erlbaum Associates Publishers.

MALOTA E. (2013): Kultúrafogalmak és modellek. In: Malota E. - Mitev A. (szerk.): Kultúrák találkozása. Alinea Kiadó, Budapest.

MALOTA E. - GYULAVÁRI T. (2014): Az észlelt kultúraszemélyiség hatása az ország turisztikai és üzleti célpontként való megítélésére. Vezetéstudomány. 45(1). pp. 2-13.

MALOTA, E. - GYULAVÁRI, T. (2016): Country Image in Relation to International Student Mobility: General Framework Proposed. International Journal of Business Insights and Transformation. 9(1). pp. 14-27.

NÉMETH K. (2017): Vidéki térségek innovációs kihívásai - Megújuló energia alternatívák. Pannon Egyetemi Kiadó, Veszprém. pp. 7376.

PÉTER E. - KELLER K. - KASZÁS N. (2013): Egészségtudatosság - része a szervezeti kultúrának? Vezetéstudomány. 44(6). Különszám. pp. 52-58.

PÉTER, E. (2015): Healthy healthcare system at Lake Balaton: Is healthy improvement or health improvement the solution for the Hungarian resort area? LAP LAMBERT Academic Publishing.

PÉTER E. - NÉMETH K. (2016): A szervezeti kultúraváltás és az emberi test múködésének összefüggései. XX. Apáczai-napok Nemzetközi Tudományos Konferencia, Széchenyi István Egyetem, Apáczai Csere János Kar, Gyôr. Absztraktok. p. 47.

PISKÓTI M. (2015): A környezeti identitás szerepe a környezettudatos viselkedés kialakulásában. Doktori (PhD) értekezés. Budapesti Corvinus Egyetem, Gazdálkodástudományi Doktori Iskola, Budapest.

PRÓNAY SZ. (2011): Ragaszkodás és én-alakítás a fiatalok fogyasztásában - A fogyasztói lojalitás és az énkép közötti kapcsolat vizsgálata. Doktori (PhD) értekezés. Szegedi Tudományegyetem, Gazdaságtudományi Kar, Szeged.

ROSSITER, J. R. (2002): The C-OAR-SE procedure for scale development in marketing. International Journal of Research in Marketing. 19(4). pp. 305-335.

TÖRÓCSIK, M. (2007): Vásárlói magatartás. Ember az élmény és a feladat között. Akadémiai Kiadó, Budapest.

TYLOR, E. (1958): Religion in Primitive Culture. Harpers \& Brothers, New York. 